\title{
Saberes, valores e crenças sobre a prática docente no discurso do professor em formação
}

\author{
Juliana Alves Assis*
}

\section{Resumo}

Tomando o discurso de uma professora de língua portuguesa em formação sobre sua primeira experiência docente, este artigo busca analisar as representaçóes sociais que orientam a ação docente e sua construção identitária. A análise dos valores e conhecimentos projetados nos dados permite tanto entrever um processo intrincado e conflituoso de construção da identidade docente, quanto revelar pistas das redes de atividades e discursos implicadas no percurso de letramento desse "ser professor".

Palavras-chave: Professores - Formaçáo. Representaçóes sociais. Identidade.

* Professora Adjunto III da Pontifícia Universidade Católica de Minas Gerai (PUC Minas), atuando na graduação e na pós-graduação em Letras. 


\section{Introdução}

A formação e a atuação de professores da educação básica têm merecido, sobretudo ao longo da última década, investimentos de pesquisa voltados, dentre outros, ora para a análise das bases teórico-conceituais e metodológicas em que se assentam projetos de formação inicial, ora para os efeitos desses percursos na construção identitária do professor, ora, ainda, para a relação, no curso dessa etapa inicial da formação, entre os saberes didáticos e científicos e os objetos de ensino/estudo com os quais o professor passará a operar em sua atividade profissional.

Dentre esses trabalhos, faz-se menção àqueles que, fugindo à lógica da valorização depreciativa que muitas vezes marcou e ainda marca a circulação de ideias sobre o professor em várias esferas sociais da atividade humana, nascem de investigaçóes de pesquisadores - também professores formadores - que, implicadas com a mudança da realidade de ensino, em seus diferentes níveis, visam à produção de saberes que efetivamente cumpram a tarefa de promoção de impactos sociais (AMIGUES, 2004; ASSIS, 2009; MATENCIO; SILVA, 2005; KLEIMAN, 2006; LOPES, 2007).

Trazida essa discussão para o campo de formação e atuação do professor de língua portuguesa como língua materna, assume-se a estreita vinculação entre o aperfeiçoamento de nossas práticas formativas e a construção de um conjunto de saberes que repercutam na transformação de representaçóes sobre a língua(gem) e seu funcionamento nas práticas sociais. Trata-se, portanto, de um investimento que, promovendo condiçóes adequadas para o processo de letramento do professor de língua portuguesa na etapa inicial de sua formação, possibilite que esse profissional se torne capaz de atuar na docência como um agente de letramento. Nos termos de Kleiman (2006, p. 88), trata-se de um professor cujas açóes visam à "colaboração e à cooperação na interação", o que instaura novo modo de produzir e negociar sentidos em torno do processo de construçáo de conhecimentos.

Nesse novo cenário, portanto, o texto - objeto de estudo/trabalho do professor - é tomado, em práticas de leitura e escrita, como realidade que se efetiva como tal por meio de açóes de construção de sentidos, nas quais se engajam, colaborativa e cooperativamente, professores e alunos, nas funçóes de autores e leitores. Disso resulta, primeiramente, que o trabalho com o texto em sala de aula deva operar com as múltiplas dimensóes nele 
implicadas, a saber: a sociopragmática, a discursiva, a textual e a linguística; em segundo lugar, e náo menos importante, que professor e aluno aprendam a se (re)construir na prática cotidiana escolar, desvencilhando-se de velhas imagens que estabelecem para esses atores papéis e posiçóes, confinados aos polos das relaçóes agente/paciente, disciplinador/indisciplinado, autoridade/subserviência, apenas para citar algumas que nós conhecemos como tradicionalmente vinculadas às figuras de professor e de aluno, respectivamente.

Considerados tais aspectos, assume-se, neste trabalho, que um dos maiores desafios postos à formação profissional docente - e aqui, especificamente, focaliza-se o professor de língua portuguesa como língua materna - é aquele que se volta para rediscutir a formação identitária profissional do professor, o que pressupóe também trazer como foco de discussão e problematização as propostas pedagógicas dos cursos de formação docente, vez que estas se conduzem pela representação do profissional que se quer construir (ASSIS, 2010).

Orientados por essas premissas, vimos, desde 2001, acompanhando, descrevendo e analisando o processo de implantação de um projeto de formação de professores da área de Letras ${ }^{1}$, o qual se alicerça na concepção de que o desenvolvimento de saberes necessários à ação docente é resultado de ações fomentadas nas e pelas interaçóes pedagógicas, nos e pelos trabalhos de pesquisa e investigação, fundamentalmente organizados na articulação reflexiva e sistemática da teoria e da prática, não se efetivando, portanto, apenas pelo domínio de conhecimentos de natureza teórica, nem estritamente por aqueles de natureza experiencial.

Entre as atividades previstas para a formação do futuro professor nesse curso acompanhado, estão as primeiras experiências docentes vivenciadas pelos estudantes - professores em formação inicial -, normalmente a partir do $4^{\circ}$ período do curso. Trata-se de atividades supervisionadas por professores formadores, com caráter de estágio curricular não obrigatório, denominadas "Oficinas de leitura e produção de textos". Por meio dessas oficinas, ofertadas a alunos dos primeiros períodos do curso de Letras e de outros cursos da mesma universidade, realiza-se um trabalho sistemático com textos acadêmicos de divulgação e de atualização do conhecimento científico produzido no domínio dos estudos sobre a linguagem (a exemplo 
de resumos, resenhas, artigos e ensaios). São, também, oferecidas oficinas de língua inglesa, nos mesmos moldes.

De 2006 até 2009, tais oficinas foram acompanhadas no que se refere às suas atividades de planejamento, execução e avaliação. Nesse empreendimento de pesquisa ${ }^{2}$, tomaram-se, ao todo, oito oficinas de língua portuguesa e uma oficina de língua inglesa, o que se deu por meio dos seguintes expedientes, nem todos utilizados em todos os semestres (período de funcionamento das oficinas):

- gravaçóes das reunióes semanais entre professores oficineiros (professores em formação) e professores orientadores, momentos em que se definem diferentes aspectos da organização e execução das oficinas;

- projeto das oficinas, elaborado pelos professores do curso que coordenam as oficinas;

- textos de referência (teóricos ou instrucionais), estudados ou sugeridos pelos professores orientadores das oficinas;

- textos de planificação do trabalho das oficinas, produzidos pelos próprios professores oficineiros (as tarefas a serem realizadas, seus objetivos, métodos, condiçóes físicas e materiais, etc.);

- registro das mensagens trocadas, através de correio eletrônico, entre os professores oficineiros e os professores orientadores, acerca do planejamento das oficinas, em lista de discussão concebida para esse fim;

- gravaçóes em vídeo de oficinas ministradas;

- textos produzidos pelos alunos, no âmbito das oficinas, e corrigidos pelos professores oficineiros;

- gravação de entrevistas com os professores oficineiros antes e após a realização das oficinas;

- gravação de autoconfrontação simples, nos termos de Clot (2001), em que professores oficineiros assistem, junto aos pesquisadores, a cenas de suas oficinas.

Neste artigo, propóe-se examinar a visão dos professores em formação acerca dessa primeira experiência docente nas oficinas aqui mencionadas. Mais especificamente, analisando o discurso de uma professora oficineira 
em uma sessão de autoconfrontação simples, realizada após o encerramento das aulas da oficina por ela ministrada ao longo do $1^{\circ}$ semestre de 2009, intenciona-se compreender representaçóes que orientam o agir da professora em sala de aula, relativamente aos objetos de ensino, aos alunos e ao seu papel na atividade. Consequentemente, busca-se flagrar pistas do processo de construção identitária dessa professora em formação.

Por meio desse expediente metodológico - a autoconfrontação simples -, assume-se, com base em Clot (2006), que se podem depreender traços do real da atividade (ou o trabalho real), que inclui, segundo o mesmo autor, o trabalho realizado pelo professor oficineiro em suas oficinas, mas vai além dele, na medida em que remete também àquilo que não se fez, àquilo que não se pôde fazer, àquilo que se buscou fazer sem se conseguir, àquilo com o que se sonha ou que se calou. É nessa dimensão que aflora a consciência discursiva dos actantes durante a situação específica de reflexão propiciada pela sessão de autoconfrontação.

\section{O solo teórico-metodológico da pesquisa}

Como assinalado, o recorte proposto para este trabalho recai sobre o discurso de uma professora em formação inicial acerca de suas ações à frente de uma das oficinas mencionadas, desenvolvidas durante o $1^{\circ}$ semestre de 2009. O trabalho nessas oficinas constitui uma etapa importante do processo de formação profissional do professor da área de Letras, uma vez que as açóes formativas levadas a efeito nesse percurso implicam a construção de conhecimentos relativos à aquisição, ao desenvolvimento e a usos da linguagem. Noutros termos, a proposta pedagógica desse curso busca assegurar ao futuro professor a compreensão do fenômeno do letramento consideradas as relaçóes entre práticas orais e escritas de produção de texto -, sua inserção no universo da escrita "letrada", bem como, sobretudo, os possíveis modos de abordagem da língua(gem) em sala de aula.

Como se pode presumir, a regência dessas oficinas impóe aos professores em formação a assunção de novos posicionamentos. Ao assumirem essa nova posição social e enunciativa, os professores oficineiros recorrem a instrumentos sociais tomados por eles como adequados à atividade na qual se engajam. Para tanto, certamente se valem das representaçóes desses instrumentos construídas em suas vivências escolares, consideradas as 
diferentes etapas de escolarização pelas quais passaram e passam, sempre na condição de alunos, ponto de vista muitas vezes em dissonância (e até mesmo em conflito) com o do professor.

$\mathrm{Na}$ construção do solo teórico-metodológico da pesquisa cujos dados se apresentam, articulam-se contribuiçóes emanadas de diferentes abordagens. Em primeiro lugar, citem-se os estudos interacionistas (BAKHTIN, 2003; VYGOTSKY, 1991; VOLOSHINOV, 1990, dentre outros autores), que defendem que os conhecimentos são elaborados, mobilizados e transformados em atividades de linguagem, as quais organizam e medeiam

as interaçóes; nessa medida, todo e qualquer texto se constrói na interação.

De modo particular, ressaltam-se os princípios emanados do quadro epistemológico proposto pelo Interacionismo Sociodiscursivo (BRONCKART, 2006, 2008), no qual as práticas de linguagem são entendidas como formas de ação a partir das condutas verbais. Adotamse, ainda, orientaçóes metodológicas inscritas na área da Ergonomia da Atividade de linha francesa, especialmente nos estudos da Clínica da Atividade de Clot $(2001,2006)$ e Faïta $(2002,2005)$ e os estudos sobre as representaçóes sociais, a partir das contribuiçóes de Moscovici (2003), na perspectiva da Psicologia Social, e de Abric (2003) e Jodelet (2001), no campo da Sociologia. Somam-se a esses estudos as contribuiçôes de Foucault (1988), notadamente no que se refere à noção de "confissão" nos discursos.

Em consonância com essa orientação teórico-metodológica, assume-se que, através das atividades de linguagem, o homem se constitui sujeito; assim, somente por intermédio delas é que tem condiçóes de refletir sobre si mesmo e sobre o mundo que o entorna. Desse ponto de vista, o desenvolvimento humano é fruto de práticas e processos de significação, os quais interessam às pesquisas sobre a formação identitária do professor. Tais práticas e processos de significaçáo são sempre orientados pelas representaçóes sociais, que funcionam como um sistema de interpretação da realidade, que rege as relaçóes dos indivíduos com o seu meio físico e social, determinando seus componentes e suas práticas. A representação social - constituída de um conjunto de informaçóes, de crenças, de opiniōes e de atitudes a propósito de um dado objeto social, estruturadas em um sistema sociocognitivo de tipo específico - é, portanto, um guia para ação e para as relaçóes sociais (ABRIC, 2003; MOCOVICI, 2003). 
Para a sessão de autoconfrontação simples (CLOT, 2001, 2006) ${ }^{3} \mathrm{com}$ a professora da oficina acompanhada - doravante KA -, foram selecionadas duas das oito aulas de sua oficina que foram gravadas, com duração de 50 minutos cada uma delas. Optou-se por não se fazer seleção prévia de cenas das duas aulas filmadas, como frequentemente se adota na utilização da metodologia da autoconfrontação, preferindo-se que essa seleção se desse no curso da sessão, a partir da tematização de KA ou das pesquisadoras que participaram da sessão. Assim, com o objetivo de suscitar em KA comentários sobre a atividade docente em foco, ela e duas pesquisadoras assistiram, juntas, a duas das aulas de KA gravadas.

À época da realização da oficina acompanhada, KA cursava o sexto período de sua formação, estando a um semestre da conclusão da licenciatura em Letras/Português. Trata-se efetivamente de sua primeira experiência em atividade docente. No percurso de sua formação universitária, KA desenvolveu projeto de iniciação científica e integra grupo de pesquisa sobre a formação de professores. A oficina ministrada - intitulada Introdução à prática de elaboração de projetos de pesquisa - contou com a participação de 15 alunos, a maioria deles do curso de Letras, porém de unidade diferente daquela de origem de KA.

A seguir, apresenta-se trecho da abertura da sessão de autoconfrontação, gravada apenas em áudio, em que a pesquisadora (P1), ao lado de bolsista de iniciação científica (P2), expóe a $\mathrm{KA}$ informaçóes sobre a sessão de autoconfrontação:

Excerto 1: abertura da sessão de autoconfrontação ${ }^{4}$.

P1: "KA... nós vamos definir aqui juntas... alguns momentos de duas aulas que a LI gravou... nas oficinas... e a gente queria que você olhasse a cena... tentando... é:: se ver de outro lugar... se ver... como dito lá... no trabalho de Rafaela Drey ... se ver de fora... que você pensasse um pouco que professora é essa que você está sendo aí... como é que você se vê... nessa cena... e que tentasse também... explicar para nós... um pouco das suas açôes... porque a gente tá vendo aqui ações... nós vamos ver açóes que você realiza... mas certamente há coisas na sua cabeça que motivaram as suas açóes... que a gente não sabe... então a gente queria que você... é... fizesse intervençóes a qualquer momento aqui... tá?"

A metodologia de autoconfrontação foi escolhida, na pesquisa, em razão de se acreditar, conforme postula Clot (2006), que, ao se auto- 
observar em sua prática, através das imagens gravadas em vídeo, o sujeito cria um diálogo interno, por meio do qual esse mesmo sujeito é afetado e, consequentemente, modificado. Assumindo a perspectiva de Bakhtin (2003), Clot (2006) assinala que o procedimento de autoconfrontação, por meio do diálogo criado com a multiplicidade de vozes presentes nos enunciados, fornece ao sujeito que fala a possibilidade de compreensão e mesmo recriação do seu trabalho.

A análise do "falar de si" pela professora KA e das açóes em que se engaja nas oficinas, vistas através da sessão de autoconfrontação, leva-nos a considerar, ainda, que a situação metodológica proposta promove condiçóes para a emergência de movimentos de "confissão". Por muito tempo ligada à prática da penitência, a confissão "difundiu amplamente seus efeitos: na justiça, na medicina, na pedagogia, nas relaçôes familiares, nas relações amorosas, na esfera mais cotidiana e nos ritos mais solenes." (FOUCAULT, 1988, p. 68). Nesse sentido, podemos falar de confissão nas observaçóes/ explicações de KA nas sessões de autoconfrontação, vista como a palavra requisitada, a qual também rompe, "por meio de alguma pressão imperiosa, as bordas entre o esquecido, o imaginado e o rememorado ${ }^{6}$." (ECKERTHOFF, 2008, p. 115).

\section{Saberes teórico-metodológicos mobilizados pelo professor em formação}

A relação que estabelecemos entre a confissão, nos termos abordados por Foucault (1988), e o discurso produzido por KA na sessão de autoconfrontação nos leva ainda a considerar, na análise desse discurso, as circunstâncias e os procedimentos adotados na coleta e geração de dados da pesquisa, tomados como parâmetros de regulação externa e transformados por KA em orientaçóes internas para seu processo de discursivização. Isso, de forma alguma - cabe assinalar - póe em questão a pertinência ou adequação do percurso metodológico adotado, já anteriormente justificado neste texto. Aliás, é exatamente a coerência com a matriz teórica adotada que nos leva a examinar os dados discursivos tendo em vista a exterioridade que os constitui.

Assim, KA, professora em formação, fala de si e de seu trabalho na oficina, assistindo à sequência de imagens de duas aulas por ela ministradas. A quem ela fala? Num primeiro plano, às duas pesquisadoras que conduzem 
a sessão de autoconfrontação (a pesquisadora coordenadora do projeto, P1, e a pesquisadora de iniciação científica, P2); num segundo plano, como desdobramento do primeiro, a uma professora formadora (sua professora em disciplinas do curso, sua ex-orientadora em projeto de iniciação científica) e a uma colega de curso (professora em formação, em sua primeira experiência como pesquisadora).

Antes de passar ao primeiro excerto da autoconfrontação a ser analisado neste artigo, vejamos a transcrição da cena de aula que será tematizada por KA em uma de suas primeiras intervençóes na sessão. $\mathrm{Na}$ cena em foco (excerto 2), KA discorre sobre os projetos de pesquisa produzidos pelos alunos da oficina, os quais lhe foram enviados por $e$-mail. No trecho da autoconfrontação (excerto 3), KA se mostra incomodada com a consideração que apresenta à aluna EL "gostei muito [...]”, após a segunda intervenção dessa aluna.

Excerto 2: trecho da oficina (aula 7) ministrada por KA.

KA: " no projeto da EL... ela coloca [...] "esta pesquisa consiste na observação e análise de metaplasmas na fala dos mineiros" "[...] lá no tema... ela colocou [...]" "o estudo dos metaplasmas... na regiáo de Belo Horizonte" [...] então... ela tem que repetir... vocês perceberam que ela repetiu? na justificativa ela repete... o que é análise de metaplasmas... então... tanto o tema quanto a justificativa se parecem e também os objetivos especificos... olha [...]" "identificar os metaplasmas a partir de gravaçóes sonoras recolhidas... objetivo geral... identificar metaplasma dialeto especificamente na regiāo de Belo Horizonte" "[...] então... gente... a sensação é essa mesmo... parece que em cada etapa a gente está repetindo tudo... (risos) mas não é isso assim... não é necessariamente isso... porque o tema ele vai dar uma visão mais global... o objetivo geral também... nos objetivos especificos as ramificaçóes... na justificativa... ai é o momento de você provar... tentar pelo menos é... argumentar porque que o seu projeto de pesquisa é importante... no problema... que você pretende responder... não é?... pra organizar mesmo o pensamento... acredito que... o projeto de pesquisa é pra organizar mesmo essa pesquisa pra gente... a metodologia que a gente já estudou... que é uma área de instrumentos... por exemplo... se eu vou fazer entrevistas... gravação... questionários... e o cronograma... todo mundo percebeu...

EL: eu mandei a metodologia... 
KA: ficou bom... eu recebi... você até trouxe já... um instrumento... um método de... pesquisa... de análise... já fez aqui o seu questionário...

EL: eu coloquei questionário...

KA: colocou... ficou bom... nós vamos discutir sobre isso... tá? mas é:: gostei muito... ((risos)) ... e então... gente... é... lá... o cronograma... uma coisa que achei esquisito... nós esquecemos de falar na semana passada que o cronograma... gente... pra toda atividade acadêmica... assim... ele é importantissimo [...]"

Nesse trecho da aula, KA realiza exposição sobre a construção composicional do gênero projeto de pesquisa, procurando, a partir de uma ilustração - o projeto de EL -, discorrer sobre a função de cada uma das partes constitutivas desse gênero. A organização de sua intervenção na aula - embora particularize o texto de um dos alunos - visa a possibilitar que o grupo de alunos possa generalizar - como ela o faz - as consideraçóes apresentadas, tendo em vista a compreensão do gênero estudado. As duas intervençóes de EL (eu mandei a metodologia... eu coloquei questionário...) parecem se construir, ao contrário, em movimento oposto ao da professora, isto é, EL toma o seu projeto de pesquisa como objeto central da reflexão, e não o gênero projeto, tal como KA parece fazer. Após as duas manifestações de EL, KA procura retomar o curso de sua exposição, voltando a tematizar o cronograma, o qual ela começara a abordar antes da primeira manifestação de EL. É exatamente essa ação que, no excerto 3, parece incomodar KA quando esta assiste à cena transcrita no excerto 2. Vejamos:

Excerto 3: sessão de autoconfrontação

KA: "essa parte aí.. quando eu digo "eu gostei muito"... eu estou falando que gostei de ela ter colocado um instrumento de coleta de dados no projeto dela... mas agora... vendo... não diz nada... quer dizer... eu estou ali aprovando o que ela fez... mas não diz nada a respeito do trabalho de pesquisa... isso ai eu fiz depois individualmente não é?... por que ficou faltando...

P1: e o que que você estava fazendo nessa hora?

Ka: oi?

P1: e o que que você estava fazendo nessa hora?

Ka: é: é... eu acredito que eu tava é... estimulando... procurando confirmar para a aluna... por que ela me perguntou... "você viu o questionário que eu coloquei no final?"... eu disse "vi... gostei muito”... será que isso é certo?" 
Na situação enunciativa tematizada por KA, podemos afirmar que os comentários feitos por ela ao projeto de EL insinuam-se, a um só tempo, como resposta ao que ela parece compreender como intenção subjacente às intervençóes de EL e como estratégia que, tomada como recurso de preservação de faces, permite-lhe retomar o fluxo temático de sua exposição antes da interrupção de EL.

A professora da oficina demonstra incômodo com relação à sua conduta verbal no trecho gostei muito, isolando-o, ao que parece, da situação de negociação em que ele emerge. Assim, KA recrimina-se, olhando, de imediato, o que pensa faltar em sua ação "mas agora... vendo... não diz nada... quer dizer... eu tô ali aprovando o que ela fez... mas não diz nada a respeito do trabalho de pesquisa." Ao mesmo tempo, também se defende com relação ao que pode suscitar no outro sua autocrítica "isso ai eu fiz depois individualmente não é?". Levada a pensar sobre sua ação por P1 "e o que que você estava fazendo nessa hora?”, hesita, procura ganhar tempo para pensar e revela uma motivação cuja legitimidade ela mesma interroga "é: é... eu acredito que eu tava é... estimulando... procurando confirmar para a aluna... por que ela me perguntou [...]" "você viu o questionário que eu coloquei no final?" [...] eu disse "vi... gostei muito"... será que isso é certo?" Com essa interrogação, sinaliza sua preocupação com os efeitos do elogio feito à aluna, como se este não se sustentasse de fato, ou revelasse algo de que ela não havia ainda se dado conta antes.

No comentário da imagem seguinte, KA evidencia o papel que atribui ao professor na tarefa de avaliação de textos, bem como a importância do retorno no processo de letramento em curso:

Excerto 4: sessão de autoconfrontação

Ka: "eu já tinha corrigido em casa... enviado e-mail... e mesmo tendo enviado por e-mail eu trouxe impresso para poder mostrar pra eles... porque muitos ainda não tinham lido né? aí eu sento para poder explicar... as dúvidas...

P1: você fala sobre cada um dos pontos que você marcou ou só aqueles que eles perguntam?

KA: só aqueles que eles perguntam... e alguns que eu acho necessário dizer... mas o tempo... e a minha ansiedade mesmo... de dar suporte para todo mundo... não permitiu que eu fizesse mesmo uma recapitulação de toda a minha correção [...]" 
Vejamos, no excerto 4, que a ação da professora na avaliação dos textos é marcada pela relevância atribuída ao diálogo, à troca, essenciais no processo da aprendizagem da interação pela escrita. Essa e outras passagens da autoconfrontação gravada indiciam, ainda, que KA toma a escrita como atividade processual, durativa. Nessa medida, não é um evento isolado nem pontual. Sob essa perspectiva, a professora em formação se inscreve, nos textos avaliados, como uma professora que convida os alunos a assumirem, também, o papel de autoavaliadores de seus textos no curso da escrita, pela reflexão cuidadosa, persistente, na busca da melhor palavra, da mais adequada forma de dizer (ANTUNES, 2006), tendo em vista os parâmetros de regulação externa da ação (através da projeção de um contexto de situação em determinada prática discursiva), que se devem transformar em representações internas capazes de orientá-los na etapa de verbalização, isto é, na mobilização de seus conhecimentos linguísticos, textuais e discursivos (SCHNEUWLY, 1988).

No esforço de levar os alunos a operarem adequadamente com o gênero projeto de pesquisa, KA explica, no excerto seguinte, que procurou construir com eles um modelo de gênero que, de forma dialógica, tomasse não somente o saber que estes possuíam sobre o gênero em foco (consideradas as versóes até então escritas), como também as especificidades de cada projeto:

Excerto 5: sessão de autoconfrontação

Ka: "quando eu falo do modelo... uma preocupação que tive em todas as oficinas... foi procurar ler... compreender cada projeto de pesquisa do aluno... pra quê? pra na oficina mesmo eu buscar relacionar na minha aula as etapas de pesquisa com cada projeto do aluno... quando eu falava daquela etapa... eu trazia ali como exemplo o assunto relacionado a uma pesquisa em especial... ali... daquela sala...por que eu acreditava que daquela maneira eles construiriam um modelo... algo mais próximo... que considerasse o que eles estavam escrevendo $[\ldots]$

Esse excerto traz pistas de que, para a professora em formação, a adoção da concepção de linguagem como interação entre sujeitos em sociedade implica a "crença na capacidade dos sujeitos de criar ou construir contextos (construcionista), de forma sempre renovada, inovadora." (KLEIMAN, 
2006, p. 26). Ela, portanto, procura organizar sua aula em um movimento que coloca em diálogo saberes e demandas dos diferentes atores envolvidos. Parece evidente que a professora em formação possui não apenas clareza sobre seu projeto de ensino como sobre o próprio objeto que ele contempla.

\section{Fronteiras e conflitos na construção identitária do professor}

De forma bastante recorrente, o discurso de KA sobre o seu agir na atividade docente constrói-se por meio do estabelecimento de fronteiras entre o que ela pretende negar (tomado como velho, desgastado ou errado) e o que deseja afirmar (visto como novo, certo ou que mais bem funciona). Noutros termos, no discurso dessa professora em formação, a referência para seu agir encontra-se, muitas vezes, balizada pela negação de uma dada forma de ser professor, presente em sua memória (eu tento náo falar tanto em sala... dominar os turnos... procuro ouvir mais os alunos... responder a suas dúvidas). Essa condução também se estende a momentos em que ela assume a posição de aluna ou tematiza sua relação com o objeto de estudo/ensino.

A posição social e enunciativa que KA é levada a assumir na regência das oficinas não se desenha sem outros conflitos, notadamente com relação à autoridade atribuída ao professor e, consequentemente, à assimetria que caracteriza a relação professor/aluno em situaçóes escolares, aspecto tematizado no excerto a seguir:

\section{Excerto 6: sessão de autoconfrontação}

KA: "que eu acho que é histórico mesmo... os meus professores... os professores dos meus avós... talvez fossem mais rigidos... é... demonstrassem... ou demarcassem mais esse lugar deles... de poder... talvez eu hoje enquanto professora... eu tento... é.. de certa forma... é... tentar contornar isso... eu não posso sair daquele lugar de professora... ele é importante pra mim... eu sou professora e não saio daquele lugar... claro... [...] mas eu não posso... assumir esse lugar de forma a prejudicar a relação estabelecida entre nós... e essa é a minha preocupação... é uma preocupação constante... minha... no meu tom de voz... às vezes no... por exemplo... no... como um aluno responde e em expressóes... se ele de repente entendeu ou não... se eu fui... foi significativo o que eu disse... se eu respondi 
às perguntas dele... se de repente eu não respondi... o que que ele vai pensar... porque é eu que direciono a aula... não é?"

Ao se ver em ação nas aulas das oficinas exibidas na sessão de autoconfrontação, KA se percebe e se descreve como professora diferente dos que a precederam (que eu acho que é histórico mesmo... os meus professores... os professores dos meus avós), rejeitando determinados traços dessa identidade de professor: a rigidez, o uso de poder na relação. É nesse momento que manifesta sua preocupação com a qualidade da interaçáo no processo de ensino/aprendizagem em curso (mas eu não posso... assumir esse lugar de forma a prejudicar a relação estabelecida entre nós... e essa é a minha preocupação... é uma preocupação constante). Em vários outros pontos da sessão de autoconfrontação, a professora em formação revela, em seu discurso, que os aspectos de ordem interacional ocupam lugar central na prática docente e na construção identitária do professor, o que pode ser lido como indicativo de que ela toma a interação em sua condição propriamente humana, ideológica, social, histórica, afetiva - discursiva, portanto.

Talvez, exatamente por isso, no excerto 7 , o silêncio na sala de aula se desenhe, aos olhos dessa professora, como um grande incômodo, pista de que ela o toma, nos termos de Laplane (2000), como um tipo particular de interação, algo veiculador de sentidos, cuja discursividade precisa ser interrogada pelo professor e náo naturalizada por ele no quadro dos acontecimentos previsíveis em sala de aula:

\section{Excerto 7: sessão de autoconfrontação}

KA: "porque... eu fico me perguntando... por que que o aluno não pergunta?... porque eu sempre fui uma aluna com muitas dúvidas... e eu... (risos) sempre perguntei... mesmo e incomodei muito os meus professores... e quando os alunos não perguntam... e... eu acredito... sempre acreditei que... a aula ela tem que ser feita de perguntas também... eu acredito que há um problema... se não aparece pergunta... não é?"

No modo de formulação a que recorre KA para falar de uma de suas características como aluna (a partir da qual ela projeta seu aluno), a consciência do conflito, em sala de aula, entre o comum e o indesejável, entre o velho e o novo, emerge na inversão construída para discorrer sobre a pergunta, na sala de aula: não mais o silêncio incomoda, e sim a quebra 
do silêncio "e eu... (risos) sempre perguntei... mesmo e incomodei muito os meus professores [...]" Trata-se, certamente, de um ponto de vista orientado pelo olhar da aluna que ela ainda é e pelos professores que compuseram sua história.

No próximo fragmento transcrito, os recursos e as estratégias de (re)construção do referente - ou seja, do objeto de discurso - também denunciam esse mesmo sentimento de dificuldade, seja por meio da organização recortada de hesitações (através das pausas, dos alongamentos), seja na reformulação que KA propóe para "posição de poder", (re)tratada, em seguida, como "posição diferenciada", forma mais opaca e menos comprometedora, na medida em que não sinaliza o status da posição "que ali eu estou numa posição de... numa posição de poder... uma posição... é:... diferenciada...", seja no intercâmbio entre os termos aluno e colega, iluminados pelo uso do operador argumentativo "até":

Excerto 8: sessão de autoconfrontação

KA: "é... e talvez... essa minha ansiedade também... e essa minha dificuldade... de acreditar que... que uma aula expositiva... ela... exija mais de mim... por quê?? que ali eu estou numa posição de:... numa posição de poder... uma posição... é:... diferenciada... quando eu estou ali... numa orientação individual... eu estou... como eu fiquei ao lado daquela aluna... estou de igual pra igual... com o... com o aluno... em muitos momentos das oficinas... eu chamava até de colega... porque eles sabem que eu também faço universidade... que eu também sou estudante [...]"

$\mathrm{Na}$ avaliação final que KA faz de aula a cujos trechos ela assiste, instigada pela pesquisadora a verbalizar sobre o tipo de professora que ela julga que foi (que professora você acha que foi nessa aula?), a professora em formação denuncia operar com uma representação negativa de professores que assumem a maior parte dos turnos ou intervençóes da aula "enquanto professora em formaçáo... isso me incomoda às vezes... o fato de falar mais do que os alunos... o professor." Pode-se dizer que KA parece associar esse perfil ao modelo de professor autoritário e mesmo pouco envolvido com a tarefa de conduzir o processo de aprendizagem, alguém que não vê ou ouve o aluno. E é exatamente com o olhar de aluna, ou seja, sob a perspectiva possibilitada por esse lugar, que KA desenha a professora que quer ser "eu tento prestar 
mais atenção... observar mais... entender o que o aluno está pensando... a dúvida que ele tem [...]"

Conduzida por essa representação de "bom professor", KA, surpreendentemente, afirma não se ver muito interativa em uma das aulas às quais assiste na sessão de autoconfrontação, mesmo tendo passado boa parte do tempo assentada com cada um dos alunos para discutir a correção que entregou; mesmo tendo usado, ao longo de toda a sua exposição, exemplos dos projetos dos alunos, por ela corrigidos "eu acredito que eu náo fui uma professora muito interativa talvez [...]"; mesmo reiterando, como em exemplos anteriormente analisados, a importância que atribui à interação no processo educativo.

No esforço de compreensão do quadro, caberia investir mais profundamente - sobretudo tendo em vista o alcance desse expediente para o aprimoramento da própria prática formativa em curso - na análise das representaçóes subjacentes a essa avaliação final da professora acerca de sua conduta, de modo a mapear suas origens e formas de circulação predominantes. Se aprendemos a partir daquilo que conhecemos e se aquilo que conhecemos se torna, em certa medida, parâmetro para a construção de novos saberes e para as nossas açóes nas práticas em que nos engajamos, a compreensão dos mecanismos e fatores implicados na construção e na transformação das representaçóes sociais deve interessar aos estudos sobre a formação do professor e sua construção identitária.

Faria sentido, sob essa lógica, também incluir discussão sobre o papel dos afetos nesse processo de formação, uma vez que se concebe, com base em Arruda (2009, p. 91), que a representação social "não cumpre uma função apenas com relação à familiarização do objeto, mas também em relação à familiaridade com o grupo, e a dimensão afetiva está na base desse trânsito, apoiada na memória, na experiência, nas contingências da situação.”

Sob esse ponto de vista, reafirma-se a pertinência de que, nos percursos de formaçáo docente, prevejam-se momentos em que o futuro professor seja levado a "se ver de fora", a falar de si, de seu agir, suas certezas, medos e dilemas, em um confronto consigo mesmo e com outras vozes presentes em sua memória. Por meio dessa estratégia, certamente se criam oportunidades para que professores formadores e em formação continuamente se (re) construam, reconhecendo-se como parte de um tecido em que se entrecruzam e se misturam o individual e o social, o circunstancial e o histórico. 


\section{Notas}

1 Trata-se do Curso de Letras da Pontifícia Universidade Católica de Minas Gerais (PUC Minas).

2 Conferir, dentre outros: Assis (2009); Assis et al. (2010); Matencio, Silva (2003); Matencio, 2002.

3 No âmbito da proposta da Clínica da Atividade, esse procedimento metodológico pode também se praticar de forma cruzada, isto é, "quando se retoma a análise em comum da mesma gravação em vídeo com um outro especialista do domínio (campo); um colega de trabalho com o mesmo nível de especialização, por exemplo.” (CLOT, 2006, p. 135).

$4 \mathrm{Na}$ transcrição, foram adotadas as seguintes normas: a) truncamento: b) qualquer pausa: c) comentários descritivos do transcritor: (minúsculas); d) citaçóes literais ou leituras de textos, durante a gravação: e) prolongamento de vogal e consoante (como s, r): podendo aumentar para ... ou mais; $f$ ) comentários que quebram a sequência temática da exposição (desvio temático): g) indicação de que a fala foi tomada ou interrompida em determinado ponto (não no seu início): [...].

5 A pesquisadora se refere a uma dissertação de mestrado, produzida na Unisinos (RS), que utiliza a metodologia de autoconfrontação.

6 Eckert-Hoff, no trabalho citado, recorre à noção foucaultiana de confissão para analisar narrativas autobiográficas de professores.

\section{REFERÊNCIAS}

ABRIC,Jean-Claude. Les représentations sociales:aspects théoriques. In: ABRIC, Jean-Claude (Org.). Pratiques sociales et représentations. Paris: Presses Universitaires de France, 2003.

AMIGUES, René. Trabalho do professor e trabalho de ensino. In: MACHADO, Anna Rachel (Org.). O ensino como trabalho: uma abordagem discursiva. Londrina: Eduel, 2004.

ANTUNES, Irandé. Avaliação da produção no ensino médio. In: BUNZEN, Clecio; MENDONÇA, Márcia (Org.). Português no ensino médio e formação do professor. São Paulo: Parábola, 2006. p. 163-180. 
ARRUDA, Angela. Meandros da teoria: a dimensão afetiva das representaçóes sociais. In: ALMEIDA, Angela Maria de; JODELET, Denise (Org.). Representaçóes sociais: interdisciplinaridade e diversidade de paradigmas. Brasília, DF: Thesaurus, 2009. p. 83-102.

ASSIS, Juliana Alves. O agir do professor em formação nas práticas de correção de textos: pistas do processo de construção identitária. Revista Estudos Lingüisticos, Lisboa, v. 38, n. 3, p. 101-118, set./dez. 2009.

ASSIS, Juliana Alves; LOPES, Maria Angela Paulino Teixeira. Ethos, discursos e representaçôes na atividade de avaliação de textos escritos: pistas de um processo de formação de professores. Revista Scripta, Belo Horizonte, v. 13, n. 24, p. 71-94, jan., 2009.

ASSIS, Juliana Alves. et al. Formação de professores de língua materna: algumas apostas. In: VÓVIO, Claudia Lemos; SITO, Luana; GRANDE, Paula Baracat de (Org.). Letramentos: rupturas, deslocamentos e repercussóes de pesquisas em Lingüística Aplicada. Campinas: Mercado de Letras, 2010. p. 179-199.

BAKHTIN, Mikhail. Estética da criação verbal. Tradução Paulo Bezerra. São Paulo: Martins Fontes, 2003.

BRONCKART, Jean-Paul. Atividade de linguagem, discurso e desenvolvimento humano. Campinas: Mercado de Letras, 2006.

. O agir nos discursos: das concepções teóricas às concepções dos trabalhadores. Campinas, SP: Mercado de Letras, 2008.

CLOT, Yves. A função psicológica do trabalho. Petrópolis, RJ: Vozes, 2006. p. 53-90.

et al. Entretien en autoconfrontation croisée: une méthode en clinique de l'activité. Education Permanente, Paris, n.146. p. 17-27, jan. 2001.

ECKERT-HOFF, Beatriz Maria. Escritura de si e identidade: o sujeitoprofessor em formação. Campinas, SP: Mercado de Letras, 2008. p. 113138.

FAÏTA, Daniel. Análise das práticas linguageiras e situações de trabalho: uma renovação metodológica imposta pelo objeto. In: SOUZA-E-SILVA, 
Maria Cecília Pérez; FAÏTA, Daniel (Org.). Linguagem e trabalho. São Paulo: Cortez, 2002.

- Análise dialógica da atividade profissional. Rio de Janeiro:

Imprinta Editorial, 2005.

FOUCAULT, Michel. História da sexualidade I: a vontade de saber. Rio de Janeiro: Graal, 1988.

JODELET, Denise. Representações sociais: um domínio em expansão. In: . (Org.). As representaçóes sociais. Rio de Janeiro: Eduerj, 2001.

KLEIMAN, Angela B. Processos identitários na formação profissional: o professor como agente de letramento. In: BOCH, Françoise; CORREAA, Manoel Luiz Gonçalves. Ensino de lingua: representação e letramento. Campinas: Mercado de Letras, 2006.

LAPLANE, Adriana Friszman de. Interação e silêncio na sala de aula. Ijuí: Unijuí, 2000.

LOPES, Maria Angela Paulino Teixeira. Relatórios de estágio: opacidade e vaguidão na análise do agir do professor. In: GUIMARÃES, Ana Maria de Mattos; MACHADO, Anna Rachel; COUTINHO, Antónia (Org.). O interacionismo sociodiscursivo: questóes epistemológicas e metodológicas. Campinas, SP: Mercado de Letras, 2007.

Atividades de (re)textualização em práticas acadêmicas: um estudo do resumo. Revista Scripta. Belo Horizonte: PUC Minas, v. 6, n. 11, p. 109-122, jul./dez. 2002.

MATENCIO, Maria de Lourdes M.; SILVA, Jane Quintiliano G. Referência pessoal e jogo interlocutivo: efeitos identitários. In: KLEIMAN, Angela B.; MATENCIO, Maria de Lourdes M. (Org.). Letramento e formação do professor: práticas discursivas, representações e construção do saber. Campinas, SP: Mercado de Letras, 2005.

; __ Retextualização: movimentos de aprendizagem. In: ENCONTRO INTERNACIONAL LINGUAGEM, CULTURA E COGNIÇÃO, 2., 2003, Belo Horizonte. Anais... Belo Horizonte: FAE/ UFMG, 2003. CD-ROM. 
MOSCOVICI, Serge. Representaçóes sociais: investigações em psicologia social. Petrópolis: Vozes, 2003.

SCHNEUWLY, Bernard. Le langage écrit chez l'enfant. Genebra:

Delachaux \& Niestle, 1988.

VOLOSHINOV, V. N. Marxismo e filosofia da linguagem. São Paulo: Hucitec, 1990.

VYGOTSKY, L. S. Pensamento e linguagem. Tradução J. Camargo. São Paulo, SP: Martins Fontes, 1991. 


\section{Knowledge, values and faith about the teaching practice on the discourse of the teacher under training}

\begin{abstract}
Taking the discourse of a teacher of Portuguese language under training about her first teaching experience, this article seeks to analyze the social representations that guide the teaching action and its identitary construction. The analysis of the values and knowledge projected on the data allows one to both glimpse an intricate and conflicted teaching identity construction process and reveal clues to the activities and discourses networks implicated in the literacy course of this "teacher being".
\end{abstract}

Keywords: Teacher training. Social representations. Identity. Literacy.

\section{Saberes, valores y creencias sobre la práctica docente en el discurso de los maestros en formación}

\section{Resumen}

Tomando el discurso de una profesora de lengua portuguesa en formación sobre su primera experiencia docente, este artículo analiza las representaciones sociales que orientan la acción docente y su construcción identitaria. El análisis de los valores y conocimientos proyectados en los datos permite tanto observar un proceso intrincado y conflictivo de construcción de la identidad docente como revelar pistas de las redes de actividades y discursos implicados en el recorrido de literacidad de ese "ser profesor".

Palabras-clave: Formación de profesores. Representaciones sociales. Identidad. Literacidad.

\section{Juliana Alves Assis}

Rua Progresso, 1.026. CEP: 30720-320 Padre Eustáquio. Belo Horizonte. Minas Gerais. Brasil.

Telefones: (31) 3412-3637; (31) 3319-4336

E-mail: juassis@terra.com.br

Recebido em: 01/7/2010

Aprovado em: 11/11/2010 